\title{
Integrated Control of Coffee Bean Borer (Hypothenemus Hampei) on Sigararutang Coffee, Motung Village, Ajibata Sub- District, Toba Samosir District, Sumatera Utara
}

\author{
Suswati $^{1}$, Sumihar Hutapea ${ }^{2}$, Rehia Isabella Barus ${ }^{3}$, Setiawan ${ }^{4}$, Ade Prayoga Hutapea ${ }^{5}$ \\ 1,2,4,5 Agrotechnology Study Program, Faculty of Agriculture, Universitas Medan Area, Indonesia \\ ${ }^{3}$ Communication Science Study Program Faculty of Social and Political Sciences, Universitas Medan Area, \\ Indonesia \\ suswati@uma.ac.id
}

\begin{abstract}
Integrated control Hypothenemus hampei in Saurdot farmer group, Motung Village, Ajibata Sub-district, Toba Samosir Regency, North Sumatra. The purpose of the activity was to increase the knowledge and skills of farmers about H.hampei and their management measures by improving cultivation techniques. The socialization of coffee borer pest management has been carried out by improving crop cultivation through spacing, crop pruning, chemical control and planting refugia plants. Partner problems are overcome by a number of technological solutions, which are carried out using technology transfer methods through education, training, demonstration plots, and mentoring. Socialization activities can increase farmers' knowledge about coffee berry borer (CBB) pests and its environmentally friendly control. The prototype of healthy coffee cultivation is very beneficial in increasing the knowledge and skills of Saurdot farmer group members in coffee cultivation. There is an increase in both knowledge and skills in the application of plant cultivation techniques. coffee specifically about the spacing of coffee seedlings increased by $15.38 \%$, the space of the shading trees around 50\%, the selection of protective trees only about 50\%, pruning coffee plants around 54\%, pruning of shading trees around 25\%, applying basic fertilizer and supplementary fertilizers around 50\% in addition, there was also an increase in the group in the introduction of plant pests and control methods. There was an increase in knowledge of partner groups about the types of coffee berry borer $(C B B)$ by $11.11 \%$, PBKo pests by $51.11 \%$, about PBKo pest control by $50 \%$ and knowledge about the types of pesticides in controlling coffee berry borer (CBB) by $50 \%$.
\end{abstract}

Keywords: coffee plant; coffee berry borer; Hypothenemus hampei; technology transfer; integrated control

\section{Introduction}

Sigararutang Arabica Coffee is one of the superior national coffee cultivars according to the Decree of the Minister of Agriculture Number: 205 / Kpts / SR.120 / 4/2005 which has been widely developed by farmers in the Saurdot Farmer group in Motung Village, Ajibata sub-district, Toba Samosir District and several regions others in North Sumatra. Sigararutang cultivar has several superior characteristics, namely dwarf type (short), excellent growth, fast fruiting and dry resistance, high productivity, relatively large seed size, and quality of flavors classified as special. In addition, Sigararutang cultivar has peel skin that is easily peeled so that it is easy to process (Randriani, Dani, \& Wardiana, 2014; Randriani et al., 2016).

In the area of Motung Village located at $\geq 1000 \mathrm{~m}$ above sea level, Sigararutang coffee plantations are planted in monoculture and multiple cropping together with tomatoes, red chili peppers, ginger, kidney beans and corn. Besides that, coffee plants are cultivated by the agroforestry method where coffee plants are planted intermittently with hard trees such as ingul trees and avocado trees. 
Based on the results of a survey conducted by Medan Area PKM team, data was obtained that the coffee plantations in Saurdot farmer group began in 1990. The plants have been replanted, so that the area of Sigararutang coffee has increased. In developing the coffee plant, various problems were found. Coffee borer pests are the main pests in coffee farming in Saurdot farmer group. The level of damage caused can reach more than $80 \%$ in untreated coffee plantations (Kumaret al, 1990; Damon, 2000; Silvaet al, 2012). These pests can cause significant losses to coffee production and prices. This is because the damage caused directly affects the decline in production, quality, and taste of seeds (Wiryadiputra 2006). Symptoms of damage can be seen from the existence of a hole in the results of scraping on coffee fruit and beans (Figure 1). PBKo pests attack fruit when they are young and are ripe. Attacks on young fruit can cause fruit decay, whereas attacks on old fruit (ripe) result in a decrease in quality (Damon, 2000; Jaramilloet al, 2006).

PBKo pests attack on coffee plantations in Saurdot Motung farm group is found to be in a relatively high level (up to 70\%). The high PBK0 pest attack is due to knowledge about pests related to life cycle, supporting factors for their propagation, how to control them and their management in general is still very low. During this time farmer group members always use Brocap traps, but in limited quantities. The use of this trap should be used in a large area and in unison with a total of 24 traps per ha. Since the price of the trap is expensive, the application does not continue. The high damage by PBKo pests is also related to not doing pruning coffee plants, so the micro climate of the coffee plant is very supportive of the development of these pests. Moreover, coffee plants are intercropped with plants that have dense and wide vegetation such as corn, tomato, red chili and ginger.

Based on the foregoing, socialization of improvements in the cultivation of Sigarautang coffee plants was carried out, especially in the management of coffee borer pests using the Sanfat 75 SP insecticide and pruning coffee plants. Taking control measures using an insecticide was decided after an assessment of damage to the coffee borer. At the time of observation data were obtained that PBKo pests in the group area had reached 100 percent with a high intensity of attacks reaching 70 percent. Based on discussions with farmer groups, a decision was made to control PBKo pests with insecticides.

The purpose of the activity is to increase the knowledge and skills of farmers about coffee borer pests, assessment of damage by coffee borer pests and effective and efficient management measures. The expected benefits of this activity are the existence of saving and the increase of coffee crop production, the increase of motivation for business development is increased.

\section{Research Method}

\subsection{Partner selection}

The partner of this activity is Saurdot farmer group, Ajibata Sub-district, Toba Samosir District, North Sumatra. The selection of farmer groups is based on farmer groups that intensively develop superior Sigarautang coffee cultivation and face coffee cultivation problems and coffee borer pests caused by Hypothenemus hampei.

\subsection{Technology Transfer}

Partner problems are overcome by a number of technological solutions, which are carried out using technology transfer methods through education, training, demonstration plots, and mentoring. Healthy coffee crop cultivation material, coffee berry borer pests (PBKo) and how to control it are delivered by counseling method (delivery of training material) using projector delivered by resource persons from Agriculture and Fisheries Office 
Budapest International Research in Exact Sciences (BirEx) Journal Volume 2, No 1, January 2020, Page: 52-61 e-ISSN: 2655-7827 (Online), p-ISSN: 2655-7835(Print) www.bircu-journal.com/index.php/birex emails: birex.journal@gmail.com birex.journal.qa@gmail.com

of Toba Samosir (Mrs. Frisda Napitupulu, SP). The process of delivering material and transferring coffee berry borer pests technology is interactive and to clarify the information submitted, a discussion session (question and answer) is opened. To obtain information about crop cultivation, coffee berry borer pests and how to control it that is applied by members of the farmer group, pre-test is done before participating in counseling and after counseling is carried out post-test. Furthermore, the results of the post-test and pre-test are processed to obtain information on the increase in knowledge and motivation of the participants in the activity.

The application of the community partnership program is continued with the improvement of farmers' skills through demonstration training activities by actively involving all participants. Training activities include the introduction of PBKo pest attack symptoms, PBKo damage assessment (calculation of attack percentage and attack intensity) followed by training in mixing liquid spray (Sanfat 75 SP insecticide) and spraying method. Improvement in the skills of the participants was measured by observing the number of participants who were able to make spray liquid in accordance with the recommendations for use in the insecticide packaging.

\section{Result and Discussion}

\subsection{Profile of Saurdot Farmers Group}

Saurdot farmer group is one of the farmer groups whose all of members grow Sigararutang coffee. This group has a membership of 25 people with an area of coffee plantations per person 0.4 ha -2.0 Ha. Members of the Saurdot farmer group are dominated by $80 \%$ of men and $20 \%$ of women and all members and administrators are married with a number of children ranging from 1-5 people. Average members aged 27-54 years with primary school education at $4 \%$, junior high school $28 \%$ and high school $68 \%$. Coffee plantations have been planted since 1990 and are still growing today. In farmland groups, coffee plants can be found with various ages ranging from planting to old plants (aged 10-15 years).

Coffee plants are generally planted on a slope of 0-30\%) which is planted monoculture or intercropped with corn and vegetable crops (red chilies, tomatoes or peanuts) (Figure 1).
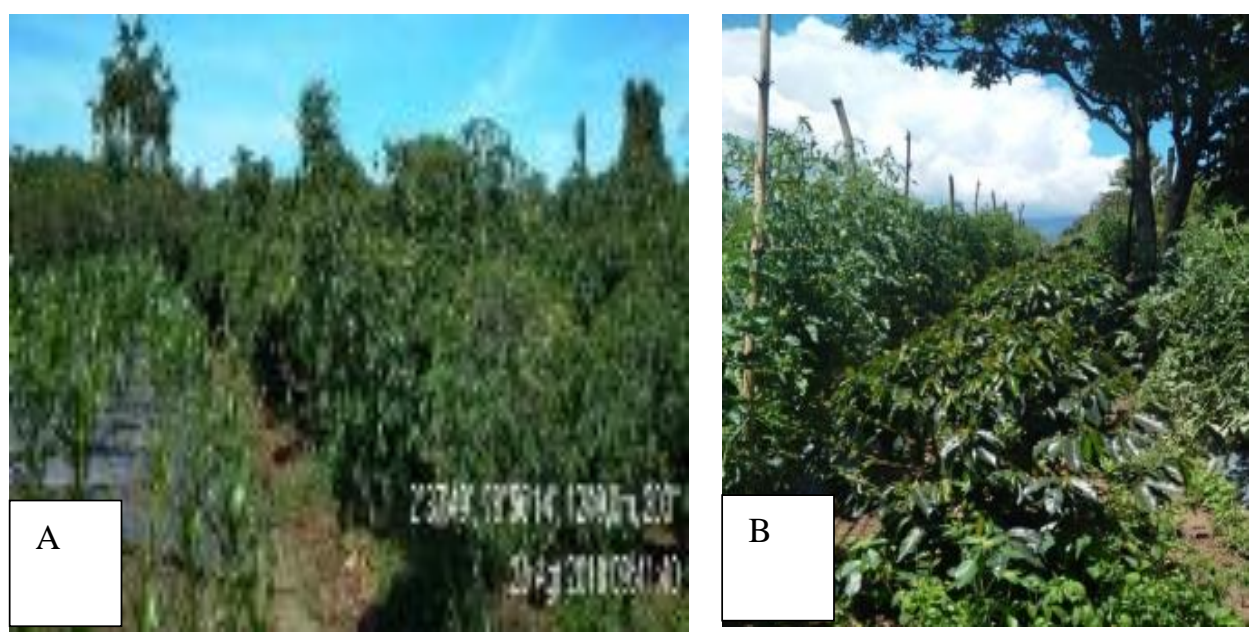

Figure 1. Coffee plants overlapped with corn (A), with tomato plants ((B)

\subsection{Current Conditions of Saurdot Farmers' Coffee Plants}

The Sigararutang variety of Arabica coffee is a type of coffee that is widely managed by Saurdot farmer groups. The reasons why farmers choose this type of coffee include: 1 . the 
Budapest International Research in Exact Sciences (BirEx) Journal Volume 2, No 1, January 2020, Page: 52-61 e-ISSN: 2655-7827 (Online), p-ISSN: 2655-7835 (Print) www.bircu-journal.com/index.php/birex emails: birex.journal@gmail.com birex.journal.qa@gmail.com

type of coffee is suitable for local climate conditions. 2. Management of plants is easier, 3. The selling price of coffee fruit is relatively high. 4. In addition, coffee plants are more resistant to climatic conditions that are sometimes not supportive, 5. This type of coffee bears fruit throughout the season (dry season and rainy season) and the early period of fruiting is faster (age 18 months has been bearing fruit).

Based on the findings in the field, the results show that: group coffee plants are generally 5-15 years old. The condition of the coffee plant was heavily attacked by coffee berry borer, twigs borer and leaf miner (Figure 3A-3D). Coffee plants appear deciduous (deciduous leaves) and many deciduous coffee fruit and scattered under the tree. Coffee fruits appear to have holes due to the attack of coffee borer (Figure 3.B).
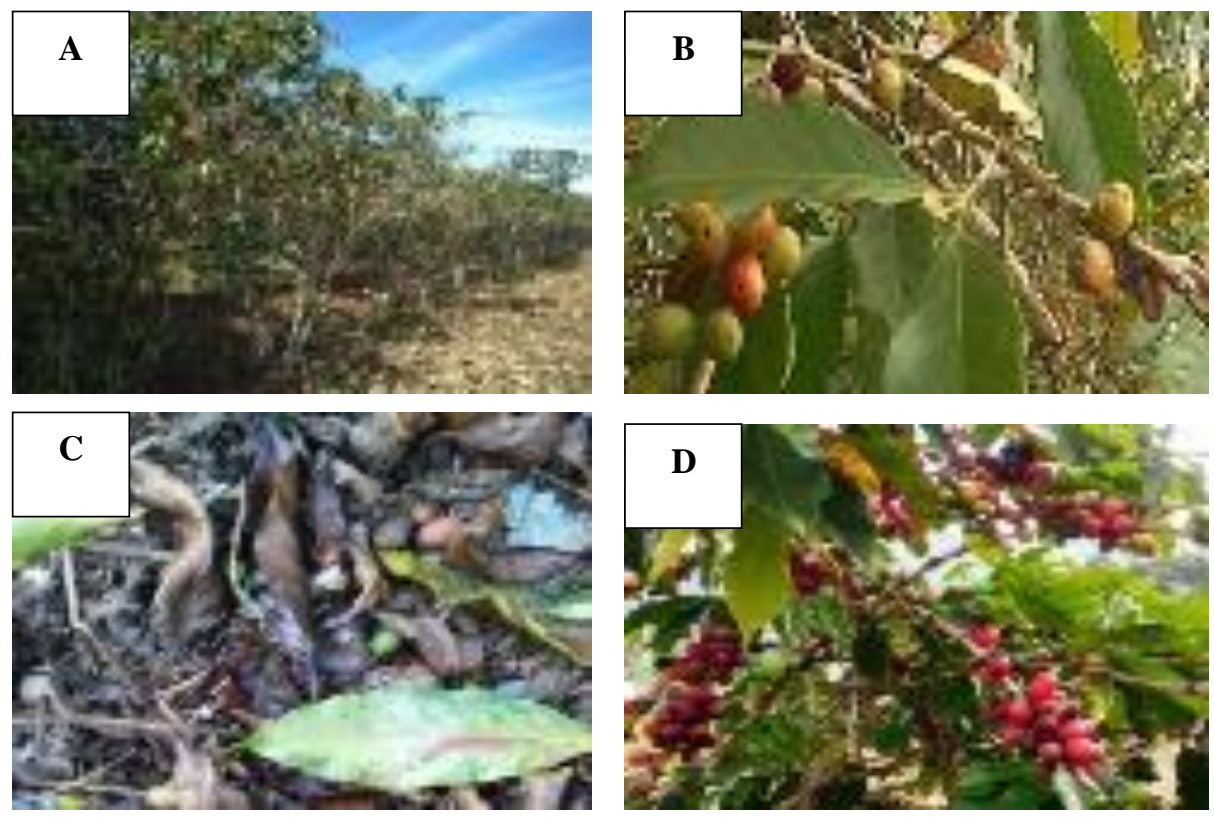

Figure 3. Condition of coffee cultivation of Saungdot Farmer group in Motung Village which is attacked by coffee borer (A). Old coffee plants without shade trees, $(B, C, D)$. Coffee fruit is attacked by PBKo. Source: Documentation of the PKM-UMA-2019 Team.

Planting conditions are very humid and dark because coffee is planted in very tight planting (planting space of $1 \mathrm{~m} \times 2 \mathrm{~m}$ ). Most coffee plantations do not have shade trees, even if there are shade trees, shade trees that are used with wide canopies such as avocado and ingul trees and no pruning.

Insects of coffee berry borer pests (PBKo) H. hampei become very damaging pests in the coffee fruit. In plants that are attacked by a decrease in production and yield quality significantly because it causes many coffee beans with holes. Loss of yield by $H$. hampei pests can reach more than 50\% if the attack is high and if proper control is not taken. Based on the results of discussions and visits to the coffee fields of Saurdot farmer group, it was found that all coffee plantations had been attacked by pests with the intensity of the PBKo attack reaching $70 \%$. Plus the long dry season from April to September, the coffee plantations will be very miserable, in flowering coffee plants appear to be falling flowers due to lack of water. Coffee fruit production is almost non-existent during the dry season. The condition of coffee plantations is very poor. 
Budapest International Research in Exact Sciences (BirEx) Journal Volume 2, No 1, January 2020, Page: 52-61 e-ISSN: 2655-7827 (Online), p-ISSN: 2655-7835(Print) www.bircu-journal.com/index.php/birex emails: birex.journal@gmail.com birex.journal.qa@gmail.com

\section{a. Socialization of Healthy Coffee Plant Cultivation, Pests and Diseases of Coffee Plants and Control Methods.}

The socialization activity was carried out at Saurdot farmer group coffee house, which was attended by 25 members of the farmer group and 3 people from Toba Samosir Balige Department of Agriculture and Fisheries (Figure 4). Dissemination on the cultivation of healthy coffee plants and their practice was carried out on the first day. Secondly, the material of pests and diseases of coffee plants and the practice of controlling coffee borer pests (Figure $5 \mathrm{~A})$.
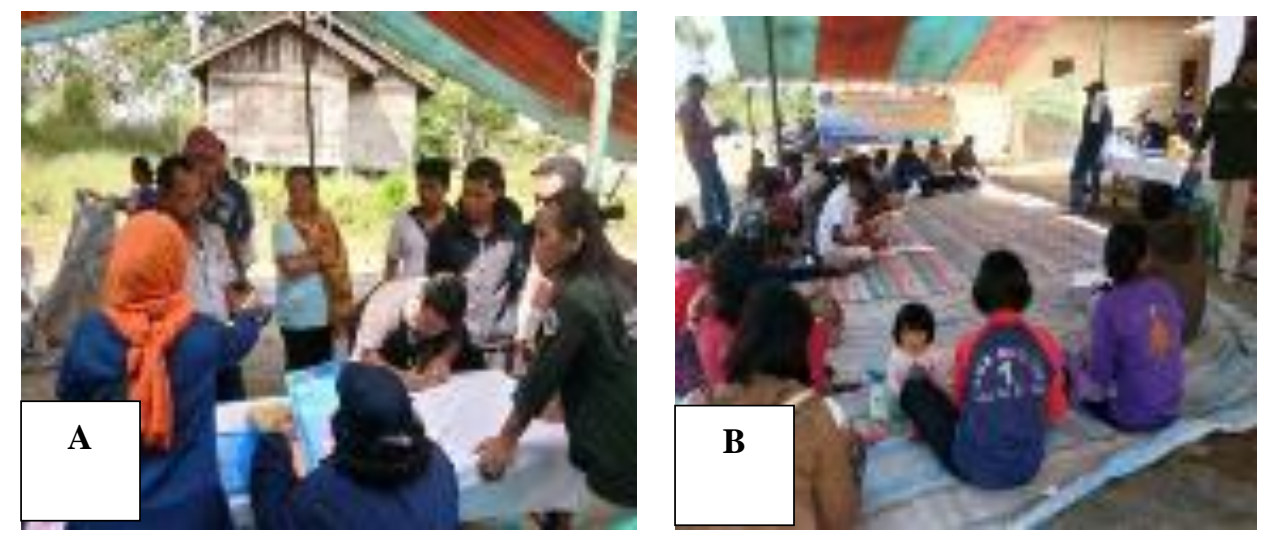

Figure 4. Registration of Coffee PKM participants (A) and filling out questionnaires, pre-test and post-test (B).

Submission of material was delivered by Mrs. Frisda Napitupulu, SP from the Tobasa Agriculture and Fisheries Service, Balige. cultivation (for demonstration plot) and pest control of coffee plants, a number of materials and tools are carried out including: 200 Sigararutang coffee seeds; 2 pieces of Solo 15 L spray equipment; 50 packs of Sanfat 75 SP insecticide (200 g); 80 bottles of liquid fertilizer; 20 sacks of Ramosdo @ 50 kg compost; Decoprima decomposer; 1 sheet of tarpaulin measuring $1.5 \mathrm{~m} \mathrm{x} 2 \mathrm{~m}$; seeds of flowering plants (kenikir, Zinnia sp, translucent, basil) (Figure 5B).
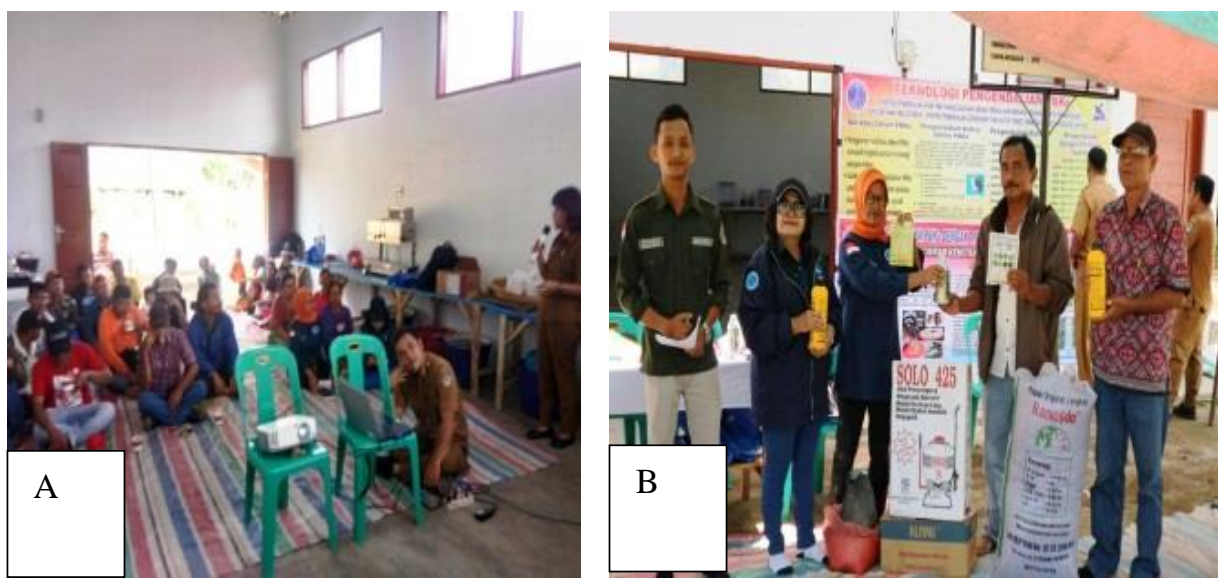

Figure 5. Extension of healthy coffee cultivation and control of PBKo (5A) and handover of materials and tools of Motung Coffee PKM (5B).

Socialization and training / practice activities are able to increase the knowledge of members of farmer groups about the cultivation of healthy coffee plants related to the use of coffee plant spacing, protective plants, pruning coffee plants / protective plants, basic 
Budapest International Research in Exact Sciences (BirEx) Journal

Volume 2, No 1, January 2020, Page: 52-61

e-ISSN: 2655-7827 (Online), p-ISSN: 2655-7835(Print)

www.bircu-journal.com/index.php/birex

emails: birex.journal@gmail.com

birex.journal.qa@gmail.com

fertilizing and subsequent fertilizers of coffee plants. Before the material was pre-tested and data were obtained that the members of the farmer groups did not understand the techniques of cultivating healthy coffee plants, which was only around $53 \%$.

The socialization activities were carried out using the lecture method, direct introduction in the farmer's garden and practice in the demonstration area of the plot of planting healthy coffee plants. The recommended spacing for coffee seedlings is $1.5 \mathrm{~m} \times 1.5$ $\mathrm{m}$ (monoculture) if coffee seed is intercropped with other plants, then a $2.5 \mathrm{~m}$ wide $\mathrm{x} 3 \mathrm{~m}$ wide spacing is used, the recommended planting hole size is $50 \mathrm{~cm} \times 60 \mathrm{~cm} \mathrm{x} 40 \mathrm{~cm}$. into the plant hole $5 \mathrm{~kg}$ of compost is added per hole. Coffee seedlings can be directly planted but compost should be incubated for 3 months. Planting a Gliricidia sepium protective tree (water wood) using a spacing of $10 \mathrm{~m} \times 10 \mathrm{~m}$. To reduce humidity in coffee plantations, it is necessary to prune coffee plants and protective plants regularly. The understanding and knowledge of group members before the pre-test of crop cultivation about the spacing of coffee seedlings around $65 \%$ and the spacing of protective trees around $40 \%$, the selection of protective trees only about $40 \%$, pruning of coffee plants around $50 \%$, pruning of protective plants around $40 \%$ and knowledge of basic fertilizers and supplementary fertilizers is around $50 \%$ (Table 1).

Table 1. Recapitulation of farmers' level of knowledge about health coffee cultivation

\begin{tabular}{|l|l|l|l|}
\hline $\begin{array}{l}\text { Farmers' knowledge about } \\
\text { coffee cultivation }\end{array}$ & $\begin{array}{l}\text { Before the } \\
\text { activity (\%) }\end{array}$ & $\begin{array}{l}\text { After the } \\
\text { activity (\%) }\end{array}$ & $\begin{array}{l}\text { Knowledge } \\
\text { enhancement (\%) }\end{array}$ \\
\hline Spacing of coffee seeds & 65 & 75 & 15.38 \\
\hline Spacing of protective trees & 40 & 60 & 50 \\
\hline Types of protective trees & 40 & 60 & 50 \\
\hline Pruning coffee plants & 50 & 77 & 54 \\
\hline Pruning protective plants & 40 & 50 & 25 \\
\hline $\begin{array}{l}\text { Provision of basic fertilizers } \\
\text { and supplementary fertilizers }\end{array}$ & 50 & 75 & 50 \\
\hline
\end{tabular}

After receiving a lot of information about the correct coffee cultivation techniques from the informants and the practice of cultivating coffee plants according to coffee cultivation standards, the knowledge and skills of group members have increased. Knowledge of the cultivation of coffee plants specifically about the spacing of coffee seedlings increased by $15.38 \%$, spacing of trees protectors around $50 \%$, selection of protective trees only about $50 \%$, pruning coffee plants around 54\%, pruning protective plants around $25 \%$ and knowledge of basic fertilizers and supplementary fertilizers around 50\% (Table 1). Expected by increasing the knowledge and skills of partner groups in the application of healthy coffee cultivation, the growth of coffee plants will get better and high production.

\section{b. Socialization of Coffee berry borer Pests (Hypothenemus hampei) and Control Methods}

Socialization activities and practices of control introduction of PBKo pests were carried out in coffee production houses followed by members of partner farmer groups. In this activity a lecture was conducted on coffee plant pest and organisms from coffee pests and diseases. Submission of material is more focused on the introduction of PBKo pests and how to control them. Biology, ecology and PBKo pest control methods were delivered by the Tobasa Department of Agriculture and Fisheries, Balige. Submission of material using projector and delivered in two directions. 
Budapest International Research in Exact Sciences (BirEx) Journal Volume 2, No 1, January 2020, Page: 52-61 e-ISSN: 2655-7827 (Online), p-ISSN: 2655-7835(Print) www.bircu-journal.com/index.php/birex emails: birex.journal@gmail.com birex.journal.qa@gmail.com

The socialization activities were carried out using the lecture method, direct introduction in farmers' gardens and the practice of spraying insecticides to control PBKo pests. Disease In the group's coffee plants found various plant-disturbing organisms such as leaf miner and coffee berry borer pests (Hypothenemus hampei), coffee rust disease (Hemileleia vastatrix). Damage by PBKo pests can be found in all coffee plantations of members and at all ages of coffee plants that have been fruitful. It appears that the fruit that was attacked by PBKo was still attached to the twigs and the fallen fruit was scattered under the coffee plant. The taking of coffee fruit that was attacked was never done so it was not surprising that PBKo pests were always high. The understanding and knowledge of group members in the pre-test of coffee berry borer (CBB) types was only about $45 \%$ and knowledge of how to control coffee berry borer (CBB) around 40\%. Knowledge of PBKo pests was $45 \%$ and PBK control by $40 \%$ (Table 2).

Table 2. Recapitulation of farmers' level of knowledge about coffee plant pests, PBKo pests and how to control them

\begin{tabular}{|l|l|l|l|}
\hline $\begin{array}{l}\text { Farmers' knowledge } \\
\text { about coffee plant pests }\end{array}$ & $\begin{array}{l}\text { Before the activity } \\
(\boldsymbol{\%})\end{array}$ & $\begin{array}{l}\text { After the activity } \\
(\boldsymbol{\%})\end{array}$ & $\begin{array}{l}\text { Knowledge } \\
\text { enhancement (\%) }\end{array}$ \\
\hline OPT types of coffee plants & 45 & 50 & 11.11 \\
\hline $\begin{array}{l}\text { Coffee berry borer pests } \\
\text { (PBKo) }\end{array}$ & 45 & 68 & 51.11 \\
\hline PBKo pest control & 40 & 60 & 50.00 \\
\hline $\begin{array}{l}\text { Types of pesticides in } \\
\text { controlling pest of coffee }\end{array}$ & 40 & 60 & 50.00 \\
\hline
\end{tabular}

The low knowledge of coffee farmers causes the low productivity and quality of coffee beans produced by the group. Coffee seeds become damaged and are unfit for further processing. In Figure 6 you can see coffee beans damaged by PBKo pests.

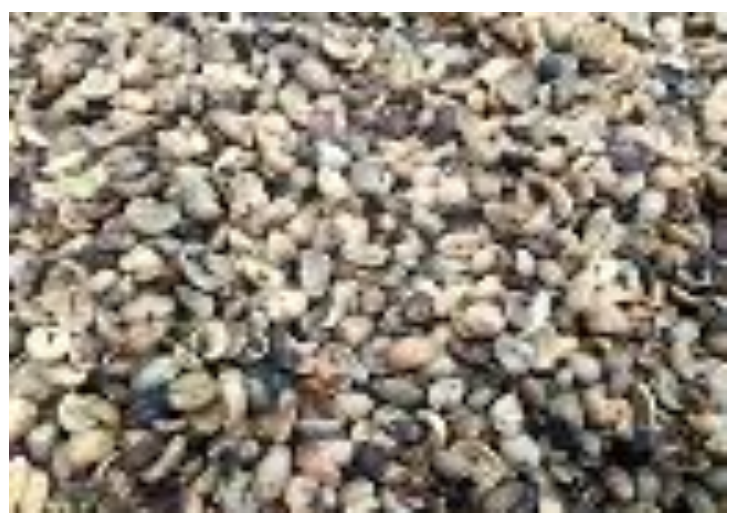

Figure 6. Display of coffee beans damaged by PBKo pests

At the pre-test, data was obtained that the farmer group did not know the types of pesticides used in coffee berry borer (CBB) control. Percentage of knowledge of farmers only get a value of $40 \%$ so it is necessary to practice mixing insecticides and spray applications in coffee plantations that are attacked by PBKo pests

In this activity farmer groups are trained in mixing insecticides and spray applications in PBKo pests affected by coffee plantations. The insecticide used in spraying practice is the Sanfat 75 SP (100 g) brand with $75 \%$ active asefate. Systemic insecticide in the form of a water-soluble flour (solubel powder) produced by PT. Santani Agro Perkasa at an application dose of $0.5-1 \mathrm{ml} /$ liter. As much as 15 liters of water is placed in a bucket then $15 \mathrm{ml}$ of 
Budapest International Research in Exact Sciences (BirEx) Journal Volume 2, No 1, January 2020, Page: 52-61 e-ISSN: 2655-7827 (Online), p-ISSN: 2655-7835(Print) www.bircu-journal.com/index.php/birex emails: birex.journal@gmail.com birex.journal.qa@gmail.com

Sanfat insecticide is added, then stirring until the insecticide flour completely dissolved. The insecticide liquid is put into a $15 \mathrm{~L}$ SOLO sprayer. The lid of the sprayer is turned tightly and tightly and pumped so that the dialect pressure reaches maximum pressure (Figure 7).
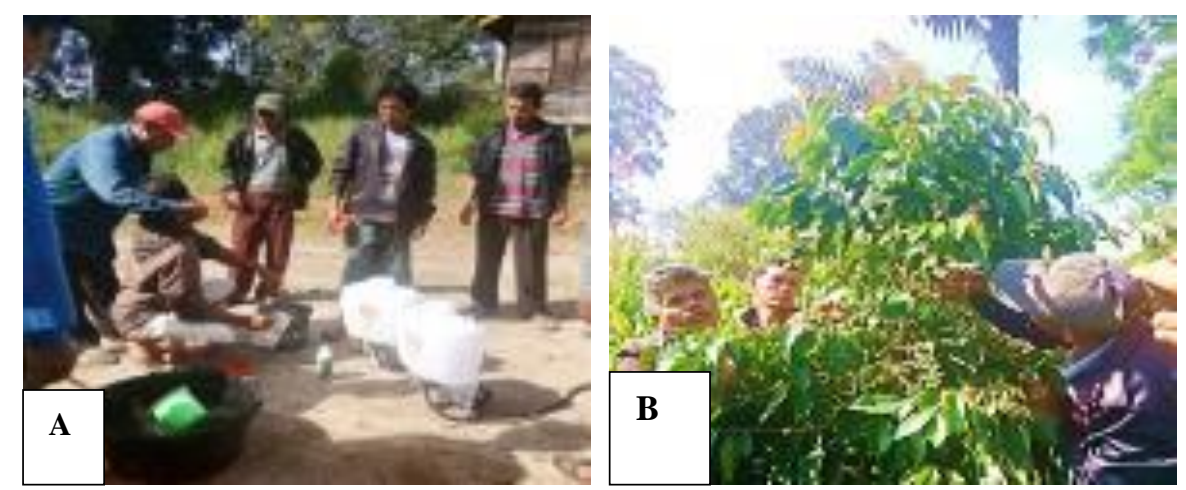

Figure 7. Stages of preparation of Sanfat 75 SP (A) insecticide spray solution and PBKo (B) pest damage assessment

Before spraying the insecticide, the farmer groups were trained to assess PBKo pest damage (percentage and intensity of PBKo damage) (Figure 7B). Data obtained that the coffee plantations in the garden have been attacked by PBKo pests, with the percentage of attacks reaching $100 \%$ and the intensity of attacks $70 \%$.

To suppress the development of PBKo pests, spraying needs to be repeated every 2 months and the PBKo population must be monitored every week. After obtaining material about the coffee berry borer (CBB), introduction of PBKo pests and how to control them, there is an increase in partner group knowledge regarding the types of pest of coffee plants by $11.11 \%$, PBKo pests by $51.11 \%$, about PBKo pest control by $50 \%$ and knowledge about the types of pesticides in controlling coffee berry borer (CBB) plants by $50 \%$.

In addition to spraying insecticides various other ways that need to be carried out to control PBKo pests are: Control of weeds in coffee plantations and around coffee plantations. Picking coffee fruit attacked by weevils (picking powder) is to start the harvest by picking all the ripe powdered rice 15- 30 days before big harvest. Powder picking has never been done in a partner group on the grounds that the attacked coffee fruit can still be harvested and the seeds are sold even though the price is low. Likewise with coffee beans that are falling and scattered under the coffee tree (parched) do not collected in the context of PBKo pest control. The activity of taking all coffee fruit at the end of the harvest (grazing / booty) is also not carried out. This causes the population of weevils to remain high because food is available all the time.

In addition to coffee plants that are intercropped with plants that have wide canopy such as tomatoes, cayenne peppers, red chilies, the width spacing must be used. This will affect the condition of the microclimate in coffee plantations. The combination will affect the growing environment such as temperature, humidity and sunlight entering the plant canopy. Environmental conditions greatly affect the ability of the $H$. hampei beetle to attack coffee fruits (Sera et al., 2010; Matielloet al, 2002). Optimum temperature for the development of $H$. hampei beetles is $20 \mathrm{oC}-33 \mathrm{oC}$. The optimum humidity for the development of PBKo ranges from $90 \%$ to $95 \%$ (Sera et al, 2010). Besides trimming coffee plants and shade trees is important to be done regularly. In addition to environmental conditions, cultivation methods also affect the level of PBKo attacks. Coffee plantations that are too tightly shaded greatly support the development of PBKo compared to plants with less shade (open). Shade 
Budapest International Research in Exact Sciences (BirEx) Journal Volume 2, No 1, January 2020, Page: 52-61 e-ISSN: 2655-7827 (Online), p-ISSN: 2655-7835(Print) www.bircu-journal.com/index.php/birex emails: birex.journal@gmail.com birex.journal.qa@gmail.com

arrangements to avoid plant conditions that are too dark are suitable for PBKo development. In the tight shade, PBKo infested fruit is 5 times heavier than the trimmed shade.

\section{c. Making a Healthy Coffee Plantation Demonstration Plot and Assisting Farmers in Implementing the Technology package}

To realize learning materials about the cultivation of coffee plants that are good and right in accordance with the Standards of coffee plant cultivation according to regulation OF the minister of agriculture number 49 / Permentan / OT.140 / 4/2014) then a Demonstration Plot (Demplot) area was established in the Mr. Haris area of $1250 \mathrm{~m} 2$ This area was previously a 15-year-old coffee plantation. The Sigararutang coffee plantation is dismantled, then in the tractor until the soil is ready for planting holes (Figure $8 \mathrm{~A}, \mathrm{~B}, \mathrm{C}, \mathrm{D}$ ).
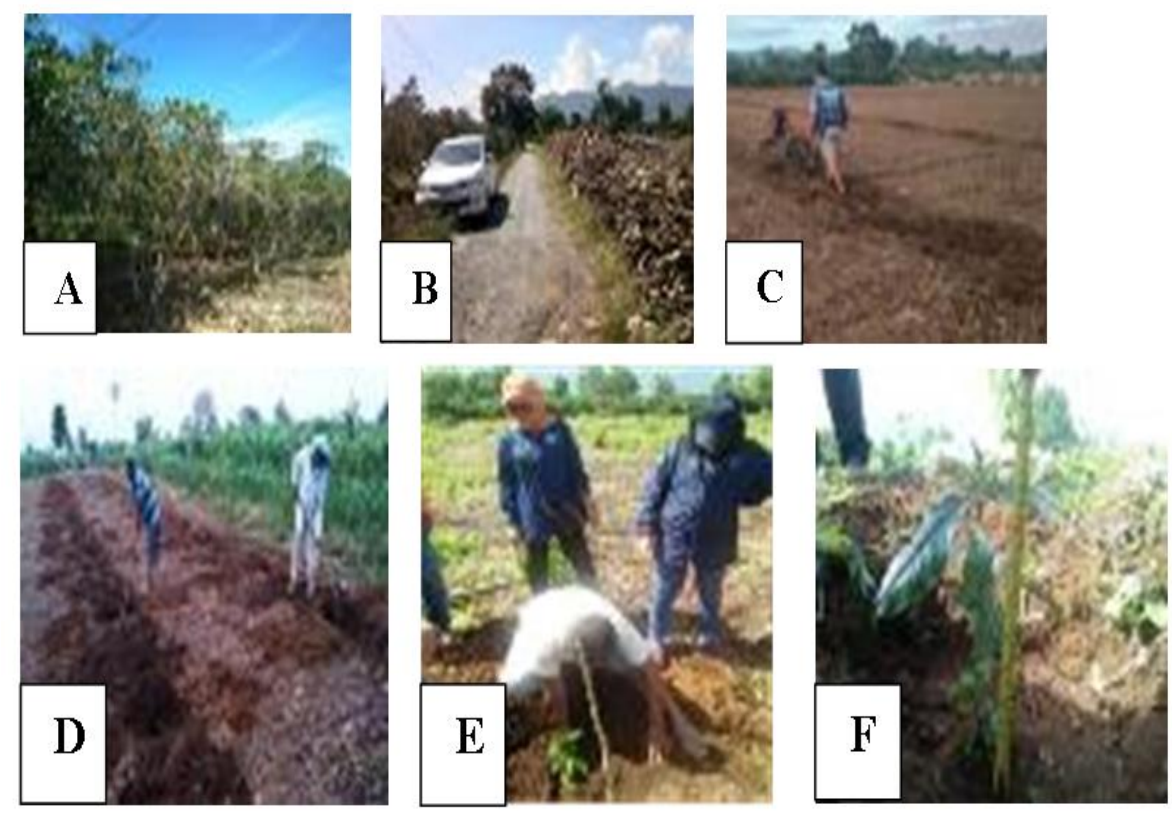

Figure 9. Stages of preparation for the location of a healthy coffee plant demonstration plot. Description: A. Coffee plantations aged 15 years; $B$. Demolition of coffee plants; $C$. Practicing; D. Making planting holes; E. Giving Ramosdo compost and planting coffee seeds; F. Sigararutang coffee seedlings.

Spacing of coffee plants $3 \mathrm{~m}$ x $3 \mathrm{~m}$ and the size of the planting hole $50 \mathrm{~cm}$ x $60 \mathrm{~cm} \times 40$ $\mathrm{cm}$. To each planting hole $5 \mathrm{~kg}$ of Ramosdo compost is added, then incubated for 3 months. After the incubation is completed, certified Sigararutang coffee seeds are planted which are propagated by the Toba Samosir District's Agriculture and Fisheries Office, Balige, North Sumatra.

To increase the growth of coffee seedlings, every $10 \mathrm{~m}$ x $10 \mathrm{~m}$ spacing, a Gliricidia sepium (water wood) tree is planted. Plants that are propagated by cuttings can already be harvested prematurely at under 1 year of age (usually 8-10 months). On the other hand, this aquatic or gamal wood plant is classified as resistant to the flea pest (Heteropsylla cubana). Another advantage of using water wood / gamal protection trees is that the leaves can be used to make bio pesticides.

To obtain data on the growth of coffee seedling, measurements of seedling growth were included plant height, number of branches and time of flowering. Until now the coffee seedlings were 3 weeks after planting (MST). Coffee plantations in the demonstration plot area serve as a model for coffee planting for members of partner groups and other coffee farmer groups in Motung Village. Plant growth is still being observed and partner groups are 
Budapest International Research in Exact Sciences (BirEx) Journal

Volume 2, No 1, January 2020, Page: 52-61

e-ISSN: 2655-7827 (Online), p-ISSN: 2655-7835(Print)

www.bircu-journal.com/index.php/birex

emails: birex.journal@gmail.com

birex.journal.qa@gmail.com

still being accompanied by PKM coffee teams from the Medan Area University. To improve the performance of natural enemies of coffee berry borer pests (parasitoid Cephalonomia stephanoderis), planting of various flowering plants such as Cosmos caudatus (kenikir), Tagetes erecta (pottery), Zinnia sp (paper flower), Ocimum sp (basil), Impatiens balsamina L (pacar air), and maintenance of many flowering weeds that grow around coffee plantations such as Ageratum conyzoides (babadotan), Bidens pilosa, Amaranthus spinosus (spiny spinach). These plants will be planted along the road in front of the demonstration plot area and inside the coffee seedlings.

\section{Conclusion}

Socialization and training activities are able to increase farmers' knowledge and skills regarding the cultivation of healthy coffee plants, the organism of coffee plant pest especially coffee berry borer pests (Hypothenemus hampei) and how to control them. There is an increase in knowledge and skills of partner groups in the application of coffee cultivation techniques specifically about the space of coffee seedlings increased by $15.38 \%$, the space of the protective tree planting around 50\%, the selection of protective trees is only about $50 \%$, pruning coffee plants around 54\%, pruning of protective plants around 25\%, providing basic fertilizers and supplementary fertilizers around $50 \%$. There was also an increase in groups in introduction of plant-disturbing organisms and control methods. There was an increase in knowledge of partner groups about the types of coffee berry borer (CBB) by $11.11 \%$, PBKo pests by $51.11 \%$, about PBKo pest control by $50 \%$ and knowledge about the types of pesticides in controlling coffee berry borer (CBB) by $50 \%$.

\section{Acknowledgement}

Thanks to the Directorate of Research and Community Service, Directorate General of Higher Education, Ministry of Research and Higher Education, for funding support through the PKM Grant with Decree Number T / 140 / E3 / RA.00 / 2019 on February 25, 2019 and Implementation Agreement Letter Partnership Program at University of Medan Area Community Number: 572 / LP2M / 04.6 / VII / 2019 on July 8, 2019.

\section{References}

Damon,A. 2000.a review of the biology and control of coffe berry borer (Hypothenemis hampei) (Coleoptera,Scotylidae).Bulletin of Entomologi cal Research,90,453-465

Jaramillo, J., Borgemeister, C., \& Baker, P. (2006). Coffee berry borer Hypothenemus hampei (Coleoptera: Curculionidae):searching for sustainable control strategies. Bulletin of Entomological Research, 96, 223-233. doi: 10.1079/BER2006434.

Kumar, P. K. V., Prakasan, C. B., \& Vijaylakshmi, C. K. (1990). Coffee berry borer, Hypothenemus hampei (Coleoptera: Scolytidae) first record from India. Journal of Coffee Research, 20(2), 160-164.

Matiello, J. B., Santinato, R., \& Garcia, A. W. R. (2002). Cultura de café no Brasil - novo manualde recomendações (pp. 387). Rio de Janeiro: Procafe Foundation.

Randriani, E., Dani, Wardiana, E., Izzah, N. K., Harni, R., Soesanthy, F., ...Sudjarmoko, B. (2016). Evaluasi varietas unggul kopi Arabika. Laporan akhir penelitian. Sukabumi: Balai Penelitian Tanaman Industri dan Penyegar. 
Budapest International Research in Exact Sciences (BirEx) Journal

Volume 2, No 1, January 2020, Page: 52-61

e-ISSN: 2655-7827 (Online), p-ISSN: 2655-7835(Print)

www.bircu-journal.com/index.php/birex

emails: birex.journal@gmail.com

birex.journal.qa@gmail.com

Randriani, E., Dani, \& Wardiana, E. (2014). Evaluasi ukuran biji beras, kadar kafein, dan mutu cita rasa lima kultivar kopi Arabika. Jurnal Tanaman Industri dan Penyegar, 1(1), 49-56. doi: http://dx.doi.org/ 10.21082/jtidp.v1n1.2014.p49-56.

Sera, G. H., Sera, T., Ito, D. S., Filho, C. R., Villacorta, A., Kanayama, F. S. Grossi, L. D. (2010). Coffee berry borer resistance in coffee genotypes. Braz. Arch. Biol. Technol., $53,261-268$.

Silva, W. D., Mascarin, G. M., Romagnoli, E. M., \& Bento, J. M. S. (2012). Mating behavior of the coffee berry borer, Hypothenemus hampei (Ferrari) (Coleoptera: Curculionidae: Scolytinae). J. Insect.Behav., 25, 408-417.

Wiryadiputra S. 2006. Penggunaan perangkap dalam pengendalian hama penggerek buah kopi (PBKo, Hypothenemus hampei). Pelita Perkebunan. 22(2):101-118. 